\title{
REPÚBLICA E RESPONSABILIDADE CIVIL DOS MAGISTRADOS
}

"Não é honesto (...) refugiar-se através da cômoda frase feita de quem diz que a magistratura é superior a toda crítica e a toda suspeita: como se os magistrados fossem criaturas sobrehumanas, não tocados pela miséria desta terra, e por isso inatingíveis. Quem se satisfaz com estas vãs adulações ofende à seriedade da magistratura: a qual não se honra adulando-a, mas ajudando-a, sinceramente, a estar à altura de sua missão."

Piero Calamendrei

(Elogio dei Giudici Scritto da um Avvocato, 1955)

\section{Rodrigo Borges Valadão ${ }^{1}$}

\section{Resumo}

O artigo 143 do Código de Processo Civil limita a responsabilidade civil dos magistrados por danos causados aos jurisdicionados às hipóteses de fraude ou dolo. Tal limitação, além de ofender o princípio republicano, não encontra fundamento no sistema de imunidades materiais previstos pela Constituição Brasileira.

Palavras-chave: Artigo 143 do CPC. Inconstitucionalidade. Princípio Republicano

\section{INTRODUÇÃO}

Não é de hoje que uma "Reforma do Judiciário" está na ordem do dia. Tópicos como a súmula vinculante, o controle externo e a unificação das regras para o concurso de ingresso na carreira da Magistratura são apenas algumas das recentes modificações na atuação do Poder Judiciário.

Todavia, uma questão muito importante tem passado ao largo de toda esta discussão. Trata-se da análise da responsabilidade do juiz pela má prestação da função jurisdicional. Não se põe, aqui, em questão, a análise de eventual responsabilidade civil do Estado por atos jurisdicionais, mas sim da responsabilidade do próprio magistrado perante o Estado ou o jurisdicionado.

Sobre o tema, a doutrina nacional costuma endossar a tese de que o magistrado só deve responder civilmente pelo seu ato jurisdicional se o mesmo encontra-se viciado por dolo ou fraude. ${ }^{2}$ No mesmo sentido, dispõe o art. 143 do Código de Processo Civil, adicionando neste rol os casos em que o magistrado, sem justo

\footnotetext{
${ }^{1}$ Doutorando em Teoria do Direito pela Albert-Ludwigs-Universität Freiburg, Alemanha. E-mail: rod_valadao@yahoo.com.br ${ }^{2}$ As críticas que serão feitas no presente trabalho devem ser estendidas a todas as demais funções públicas que, por lei, sejam beneficiadas por semelhante "prerrogativa".
} 
motivo, recusar, omitir ou retardar medidas que deve ordenar de ofício ou a requerimento da parte.

Como fundamento metajurídico desta norma, costuma-se dizer que "a independência funcional, inerente à Magistratura, tornar-se-ia letra morta se o juiz, pelo fato de ter proferido decisão neste ou naquele sentido, pudesse ser acionado para compor perdas e danos, em favor da parte que sucumbiu”. ${ }^{3}$

Todavia, no direito comparado, notadamente no americano e no europeu, a questão não é encarada de forma tão simplória. Desde a década de 80, pelo menos, a questão já vem sendo debatida em congressos ${ }^{4} \mathrm{e}$ periódicos $^{5}$, sendo, no entanto, ponto pacífico que é necessária a previsão legal de um eficaz sistema de responsabilização pessoal do juiz, em sede criminal, disciplinar e civil.

Especificamente sobre o caso italiano, relata Mauro Capeletti que

"não era concebível que (...) se pudesse perpetuar um sistema judiciário carente, ao mesmo tempo, de profissionalidade e de responsabilidade: ou seja, um ordenamento no qual os juízes, tendo assumido a magistratura sem base em séria aprendizagem e avançado na carreira substancialmente com fundamento apenas na antiguidade, ficassem, outrossim, completamente imunes de responsabilidade perante as partes e outros sujeitos prejudicados por atos ou omissões viciadas de culpa, inclusive gravíssima do magistrado (....." ${ }^{6}$

A latente semelhança desta constatação com o caso brasileiro deve reforçar a convicção de que é necessário rever o nosso sistema, ancorado, segundo a doutrina majoritária, tão-somente no dolo ou na fraude.

Em síntese, o que se pretende através do presente trabalho é demonstrar que a limitação da responsabilidade dos magistrados, pelo exercício da função jurisdicional, aos casos de dolo ou fraude ofende o princípio republicano, positivado no art. $1^{\circ}$ da Constituição de 1988. Como conseqüência, será proposta uma nova interpretação ao referido dispositivo da lei processual civil, de sorte a compatibilizá-lo com o ordenamento constitucional vigente.

Diante do enorme poder concentrado nas mãos dos juízes para o melhor desempenho da função jurisdicional, sua responsabilidade pessoal não pode ficar relegada, numa conveniência hipócrita, ao esquecimento. Em formulação que até as crianças já conhecem, a advertência é exatamente a mesma feita pelo personagem de histórias em quadrinhos Tio Ben ao seu sobrinho Peter Parker (o Homem-Aranha): “- Grandes poderes trazem grandes responsabilidades". Esta é, em síntese, a lição que temos que aprender com elas.

\footnotetext{
${ }^{3}$ Estas são as palavras de Yussef Said Cahali. Apud. CAVALIERI, Sérgio. Programa de Responsabilidade Civil, $5^{a}$ ed., São Paulo: Malheiros, 2003, p. 267.

${ }^{4}$ Veja-se, por exemplo, o XI Congresso Mundial da International Academy of Comparative Law, realizada em Caracas, entre os dias 30 de agosto e 04 de setembro de 1982, que teve como tema justamente os debates acerca da necessidade de um sistema de responsabilização dos magistrados.

5 Neste particular, ressalte-se os debates travados em 1983, na American Journal of Comparative Law, cujo editorial indicava a problemática, com o tema "Who Watches the Watchmen?: a Comparative Study on Judicial Responsability".

${ }^{6}$ CAPELETTI, Mauro. Juízes Irresponsáveis?, Porto Alegre: Sérgio Antônio Fabris Editor, 1989, p. 8.
} 


\section{PRINCÍPIO REPUBLICANO E RESPONSABILIDADE}

É realmente difícil encontrar, na literatura jurídica nacional, estudos sobre o princípio republicano. Não se trata, aqui, da história da nossa República ou da teoria republicana, esta última em notável refluxo na escola francesa e salutarmente abordada pela literatura nacional. De fato, nos enfoques histórico e político, estamos bem servidos.

No âmbito estreito da ciência do direito é que esta omissão revela-se mais acentuada. É realmente raro encontrar nos manuais de Direito Constitucional, ou mesmo nos de Teoria Geral do Estado, uma linha sequer destinada aos aspectos jurídicos do princípio republicano. ${ }^{7}$ Talvez a arraigada concepção patrimonialista do Estado Brasileiro ainda seja muito forte no inconsciente coletivo dos juristas.

Se, de um lado, a história bem tem cumprido seu papel no estudo das forças que operaram no decorrer de nossa história republicana ${ }^{8}$, e, de outro, a ciência política, que vem resgatando o valor intrínseco da liberdade humana, ${ }^{9}$ a ciência do direito pouco - ou nada - avançou na consolidação do princípio republicano.

Sobre o tema, registre-se o notável esforço empreendido por Geraldo Atalida, que figura sozinho no rol dos autores nacionais que dedicaram uma obra monográfica ao tema. ${ }^{10}$ Logo em sua introdução, define República como "o regime político em que os exercentes de funções políticas (executivas e legislativas) representam o povo e decidem em seu nome, fazendo-o com responsabilidade (...). ${ }^{11}$ E continua mais adiante: "a simples menção ao termo república já evoca um universo de conceitos intimamente relacionados entre si, sugerindo a noção do princípio jurídico que a expressão quer designar. Dentre tais conceitos, o de responsabilidadeé essencial”. ${ }^{2}$

De fato, a República é uma forma de governo ${ }^{13}$ que pressupõe a possibilidade de participação do povo no governo, estando, pois, intimamente ligado ao conceito de democracia. ${ }^{14}$ Tanto é assim que, durante o século XVIII, muitos teóricos e líderes políticos pregavam a abolição da monarquia e a afirmação da soberania popular.

\footnotetext{
${ }^{7} \mathrm{O}$ mesmo, contudo, não pode ser dito sobre as disposições constitucionais que instituem algumas prerrogativas aos membros do Poder Judiciário e do Ministério Público. Neste particular, são numerosos e volumosos os trabalhos monográficos.

${ }^{8}$ Cf. PENNA, Lincoln de Abreu. República Brasileira. Rio de Janeiro: Nova Fronteira, 1999, p. 29 e seguintes.

${ }^{9}$ Cf. BERTEN, André. Republicanismo e Motivação Política. In: Direito e Legitimidade, São Paulo: Landy Editora, 2003, p. 21 e seguintes et PETTIT, Philip. Republicanismo (Uma Teoria sobre la Liberdad y el Gobierno). Barcelona: Paidós, 2000, p. 35 e seguintes.

${ }^{10}$ Esta afirmação tem por base uma pesquisa realizada em 3 (três) grandes bibliotecas da cidade do Rio de Janeiro: a biblioteca da Fundação Getúlio Vargas, a biblioteca da Pontifícia Universidade Católica (PUC) e a biblioteca da Procuradoria-Geral do Estado do Rio de Janeiro. Nesta pesquisa, esta foi a única obra jurídica encontrada que se dedicou exclusivamente ao tema "República”.

${ }^{11}$ In: Constituição e República, 2a ed., São Paulo: Malheiros, 1998, p. 13.

12 Idem, p. 65.

${ }^{13}$ Para quem não se lembra dos conceitos, todo Estado é dotado de governo, que, por sua vez, possui uma forma e um sistema. A forma de governo, que diz respeito ao modo de acesso ao poder político, pode ser a monárquica ou republicana. No primeiro, o acesso é hereditário e vitalício; no segundo, o acesso é por mandato e temporário. O sistema de governo, por sua vez, indica o modo pelo qual se dá a relação entre os Poderes de Estado, notadamente Legislativo e Executivo. No presidencialismo há separação entre eles; no parlamentarismo, ambos funcional em colaboração mútua.

${ }^{14}$ DALLARI, Dalmo de Abreu. Elementos de Teoria Geral do Estado, 20ª ed., São Paulo: Saraiva, 1998, p. 227.
} 
Acreditava-se, pois, que a República era a única expressão democrática de governo, por ser o regime de governo onde há efetiva limitação do poder dos governantes, tendo em vista a possibilidade de atribuição de responsabilidade política aos mesmos.

Nascem, assim, as Repúblicas Modernas, norteadas pela idéia de que o governante não exerce seu poder em nome próprio, mas em nome do povo, o que, em última análise, significa que é o mesmo politicamente responsável, devendo prestar contas ao povo, de forma direta ou através de um órgão de representação popular. ${ }^{15}$ É exatamente nisto que se opõe a República às demais formas de governo, principalmente a Monarquia, regime de governo no qual quem exerce função política é irresponsável e, por isso, investido vitaliciamente. ${ }^{16}$

\section{Princípio Republicano e Função Jurisdicional}

Uma análise apressada pode levar a crer que o princípio republicano, por dizer respeito à forma de governo do Estado brasileiro, não seria dirigido à função jurisdicional. Todavia, quer se considere a função jurisdicional como uma função técnica ou como uma função política, o princípio republicano deve informar seu exercício, através da implementação de responsabilidade ao agente que venha a provocar danos a terceiros.

\section{A Função Jurisdicional como Função Técnica}

Talvez, a parca produção jusliterária nacional sobre responsabilidade dos magistrados deva-se, além da nossa tradição patrimonialista, à idéia de que o Poder Judiciário exerça uma função técnica, de mera aplicação do direito aos casos concretos. ${ }^{17}$

Deste modo, por não exercer o Poder Judiciário uma verdadeira função política, mas sim meramente técnica, não haveria obrigatória incidência do princípio republicano. Sem questionar a premissa de que a atividade jurisdicional tem caráter meramente técnica - premissa esta que será atacada no tópico seguinte -, é importante ressaltar que o reconhecimento de responsabilização não decorre necessariamente da idéia de representação direta do povo.

Na formulação de Geraldo Ataliba,

"se (...) a função judicial consiste em dar aplicação à lei nos casos contenciosos, mediante interpretação técnica e aplicação imparcial, sendo a lei primeira e precípua fonte do Direito guardada, evidentemente, a hierarquia constitucional - e sendo este, na república representativa, expressão do órgão da representação popular, por excelência, os seus integrantes (do Poder Judiciário) precisam ser bons técnicos, destros na função

\footnotetext{
${ }^{15}$ Idem, p. 229.

${ }^{16}$ ATALIBA, Geraldo. Constituição e República, 2a ed., São Paulo: Malheiros, 1998, p. 65.

${ }^{17}$ Este fato foi originalmente notado pelo meu aluno do curso de graduação em direito da Universidade Estácio de Sá, Campus Friburgo, Roni Vieira de Aguiar, em sua monografia "O Controle Externo do Judiciário e a Atividade Judicante", a qual tive a honra de orientar.
} 
hermenêutica e não representativos. Juiz faz justiça. E, no nosso sistema, fazer justiça é aplicar correta, objetiva e imparcialmente a lei (...)" ${ }^{18}$

Se o magistrado não aplica a lei de forma correta, significa que o mesmo falhou em sua atuação funcional, demonstrando não dominar a técnica de modo satisfatório. E se o fez, frustrou as mais legítimas expectativas republicanas, de aplicação objetiva e imparcial das leis. Como agente a serviço da República, não demonstrou a necessária presteza técnica e, por isso, deve responder perante o povo por seus atos.

Assim sendo, encampando-se a idéia de que a função jurisdicional tem natureza técnica, nada mais natural que a falha técnica dê margem à responsabilização pessoal do agente quando ele tiver frustrado os anseios republicanos, cristalizados no ideal de soberania popular e império da lei, sendo esta expressão daquela.

Logo, é forçoso reconhecer que não somente os mandatários (ou seja, aqueles que ocupam cargos eletivos), são destinatários do princípio republicano. Todo aquele que exerce poder (aqui entendido o poder como função pública, independentemente de sua natureza política ou técnica) em um Estado Republicano deve ser, necessariamente, responsabilizado pelos seus atos funcionais.

\section{A Função Jurisdicional como Função Política}

É verdade que, na maioria dos Estados Democráticos Modernos - principal-mente naqueles em que o Poder Judiciário foi alçado à condição de Poder de Estado -, consagrou-se a arraigada convicção de que só tem cabimento a aplicação do princípio da representatividade aos órgãos executivos e legislativos. Desta forma, apenas aqueles que fossem mandatários do povo poderiam exercer funções políticas.

Trata-se de um grave erro de perspectiva que, se embora fosse justificável no século XIX, ${ }^{19}$ desde o início do século XX, já não encontra mais substrato doutrinário sólido.

De fato, fica cada dia mais evidente que o magistrado, ao exercer a função jurisdicional, exerce enorme parcela de poder político. Por meio da interpretação não se busca a vontade da lei para o caso concreto. Na verdade, se por interpretação se entende a fixação por via cognitiva do sentido do objeto a interpretar, o resultado de uma interpretação jurídica somente pode ser a fixação da moldura que representa o direito a interpretar e, conseqüentemente, o conhecimento das várias possibilidades que dentro dessa moldura existem. ${ }^{20}$ Dentro desta moldura, o direito a ser aplicado no caso concreto é criado por um ato político do magistrado, segundo suas

\footnotetext{
${ }^{18}$ Idem, p. 113.

19 Para Montesquieu, por exemplo, o Legislativo e o Executivo eram Poderes eminentemente políticos, que se controlariam reciprocamente, nos limites de suas competências, sendo o Judiciário um poder nulo em relação a sua participação política no Estado, a quem caberia, apenas, exercer o controle de legalidade dos demais Poderes e cuidar das mazelas entre particulares. In: BONAVIDES, Paulo. Teoria do Estado. 6a ed., São Paulo: Malheiros, 1996, p. 160.

${ }^{20}$ KELSEN, Hans. Teoria Pura do Direito, 2a ed., São Paulo: Martins Fontes, 2001, p. 390.
} 
íntimas convicções de justiça. ${ }^{21}$

A técnica jurídica, portanto, apenas indica os limites formais, ou seja, exclui do debate político certas soluções para o caso concreto, fornecendo uma moldura para a atuação válida do magistrado. Assim, de um lado, a função jurisdicional contém um momento jurídico, que é a definição, a ser extraída através da interpretação das normas jurídicas, da moldura fornecida pelo ordenamento, e um momento político, que é a escolha pelo magistrado, segundo seus valores pessoais, de uma das alternativas contidas dentro da moldura.

Deste modo, todo ato de aplicação do direito é, ao mesmo tempo, um ato de criação do direito. Há, portanto, o desempenho de uma verdadeira função política por parte do magistrado, sempre que profere uma decisão jurisdicional. Deste modo, estará a mesma sempre sujeita ao controle jurídico (controle de legalidade) e ao controle político (controle de legitimidade), se, de fato, queremos falar de uma República.

Além desta constatação científica, uma constatação histórica também aponta para a crescente politização da função jurisdicional. É que, ao lado da natureza da função jurisdicional, que como foi visto possui uma considerável parcela política, a própria dinâmica das sociedades modernas determinou um notável crescimento do Poder Judiciário.

Em primeiro lugar, como conseqüência do advento dos Estados de Bem-Estar Social (Welfare States), em que houve uma extraordinária expansão das funções legislativa e administrativa, verificou-se a exigência de maior controle destes atos pelo Poder Judiciário, o que levou o processo para além dos limites da lide essencialmente privada. ${ }^{22}$ Note-se, aqui, o surgimento de novos direitos, os direitos sociais, que, para serem garantidos, exigiram cada vez mais uma postura ativa da função jurisdicional.

Em segundo lugar, consolidou-se a tendência de se abandonar a concepção do processo civil como mero negócio das partes e do juiz como árbitro passivo, privado de controle sobre o desenvolvimento do processo. ${ }^{23}$ Como exemplo, note-se o movimento para oralidade no processo, que conduziu ao aumento da função do juiz na sua condução, seja no sentido de controlar ou acelerar o seu desenvolvimento, seja no sentido de assegurar a igualdade material das partes, seja no sentido de garantir a efetividade da prestação jurisdicional.

Em terceiro lugar, sentiu-se a necessidade da tutela de interesses que transbordam os interesses individuais, o que levou à criação do que se convencionou tutela jurisdicional dos interesses difusos e coletivos. Numa sociedade de massas, onde um ato pode trazer danos a toda coletividade, a visão exclusivamente intersubjetiva do processo, tradicional na dogmática jurídica, não mais se demonstrou suficiente, levando a ciência

\footnotetext{
${ }^{21}$ Segundo Piero Calamandrei, "mesmo que o juiz pudesse esquecer, enquanto julga, suas opiniões e sua condição pessoal, sempre teria o dever, para aplicar fielmente a lei, de interpretá-la. Mas interpretá-la quer dizer remontar à ratio de que nasceu, isto é, substancialmente à inspiração política que circula nela e a torna socialmente atual. O que leva a considerar que, em toda interpretação jurídica, há certa margem de opção política”. In: Eles, os Juízes, Vistos por um Advogado. São Paulo: Martins Fontes, 1995, p. 245.

${ }^{22}$ CAPELETTI, Mauro. Juízes Irresponsáveis?, Porto Alegre: Sérgio Antônio Fabris Editor, 1989, p. 21.
} 
do direito a elaborar novos conceitos, adaptando a função jurisdicionai aos novos anseios sociais.

Por fim, novas técnicas legislativas e jurídicas surgidas vieram a aumentar substancialmente os poderes dos magistrados. Como exemplo da primeira, veja-se a adoção cada vez maior pelos ordenamentos dos conceitos jurídicos indeterminados, que aumentam, de forma considerável, a moldura de atuação do magistrado. Como exemplos da segunda, tem-se a consagração doutrinária dos postulados ${ }^{24}$ da razoabilidade ${ }^{25}$ (pelo qual o magistrado poderá averiguar se a medida legislativa ou administrativa atende aos fins consagrados pelo ordenamento), e da ponderação ${ }^{26}$ (pelo qual busca-se a solução para os casos de conflito ocorridos dentro do mesmo documento jurídico).

Não há, portanto, como negar que, na atualidade, a função jurisdicional tem um traço político deveras acentuado. E, com isto, aumenta-se o poder do magistrado. Ocorre que, como bem acentua Mauro Capeletti, "onde há poder deve haver responsabilidade: em uma sociedade racionalmente organizada [leia-se: numa República] haverá uma relação diretamente proporcional entre poder e responsabilidade”. ${ }^{27} \mathrm{E}$ continua adiante: "um poder não sujeito a prestar contas representa a patologia, ou seja (...), falta de organização racional, o que em ciência política pode-se simplesmente rotular de autoritarismo e, na sua expressão extrema, de tirania”. ${ }^{28}$

\section{Para Além da Responsabilidade Política: as Esferas Criminal, Disciplinar e Civil}

Como foi visto, a responsabilidade é a contrapartida dos poderes enfeixados pelo agente público. Todos aqueles que agirem, em qualquer área ou nível, como integrantes de algum órgão público ou exercendo uma função pública devem ser juridicamente responsáveis pelos seus atos e omissões. Mas, para a efetivação desta responsabilidade, é preciso admitir que o agente do poder público ou o exercente de função pública possam ser chamados a dar explicações, por qualquer pessoa do povo, por um grupo social definido ou por um órgão público previsto na Constituição da República como agente fiscalizador. ${ }^{29}$ Se a coisa pública pertence ao povo, perante este todos os seus gestores devem responder.

Numa República, a responsabilidade pode assumir diversas facetas. É verdade que, num primeiro momento, esta responsabilidade assume natureza eminentemente política. Assim, o povo - ou outro órgão de

\footnotetext{
${ }^{23}$ Idem, p. 20 e seguintes.

24 Utiliza-se, aqui, a classificação das normas jurídicas proposta por Humberto Ávila, que as divide em regras, princípios e postulados normativos. Cf. Teoria dos Princípios. 4a ed., São Paulo: Malheiros, 2005.

${ }^{25}$ Sobre o postulado da razoabilidade, confira-se a didática obra de Luis Roberto Barroso. In: Interpretação e Aplicação da Constituição, 6a ed., São Paulo: Saraiva, 2004, p. 218 e seguintes.

${ }^{26}$ Cf. BARROSO, Luis Roberto et BARCELLOS, Ana Paula de. "O Começo da História: a Nova Interpretação Constitucional e o Papel dos Princípios no Direito Brasileiro”. In: A Nova Interpretação Constitucional, Rio de Janeiro: Renovar, 2003 , p 344 e seguintes.

${ }^{27}$ Op. Cit., p 18.

${ }^{28}$ Idem, p. 18.

${ }^{29}$ DALLARI, Dalmo de Abreu. Constituição e Constituinte. São Paulo: Saraiva, 1982, p. 66
} 
representação política - pode, na forma prevista pela Constituição, cassar o poder outorgado ao agente público que, conforme seu entendimento, tenha agido em contrariedade aos interesses coletivos. ${ }^{30}$

Todavia, longe de se exaurir na esfera política, a responsabilização do agente pode ter conseqüências jurídicas, configurando-se como crime, como ato desabonador da honra objetiva das instituições juspolíticas ou como ilícito civil. Surgem, assim, respectivamente, as responsabilidades criminal, disciplinar e civil do agente público.

As 2 (duas) primeiras, por fugirem aos objetivos deste trabalho, não serão abordadas. Quanto à responsabilidade civil, deve ser apontado, logo de início, que os textos constitucionais brasileiros não contêm uma regra explícita para o caso dos magistrados. Não obstante, a atenta consideração das exigências do regime republicano leva à convicção de que os mesmos são passíveis de responder civilmente pelos danos que alguns dos seus atos possam eventualmente provocar ao Estado ou a terceiros.

Se o particular, em sua esfera exclusivamente privada, vier a provocar danos injustos a terceiros, sua conduta será rechaçada pelo direito com a responsabilização civil e conseqüente condenação de reparar o mesmo. Por que a regra deveria ser diversa para o agente público que, tutelando coisa alheia (res publica), vier a provocar dano injusto ao Estado ou a terceiro?

Outrossim, se o próprio Estado é, como qualquer pessoa, sujeito à jurisdição, como não será um dos seus principais agentes? Se este precisa dispor de garantias que lhe assegurem condições objetivas de liberdade no decidir sobre questões fundamentais, de interesse público, por outro lado, a coisa pública, com maior razão mormente contra suas decisões injurídicas e danosas -, precisa ser protegida.

Logo, os excessos e os desvios de poder, ao lado de decisões manifestamente imprudentes, devem dar ensejo à responsabilização civil, seja regressiva, seja ordinária, quando o lesado é o patrimônio público ou privado. Nada, absolutamente nada, autoriza uma solução diversa.

\section{A INCONSTITUCIONALIDADE DA LIMITAÇÃO A RESPONSABILIZAÇÃO CIVIL DOS MAGISTRADOS: A NECESSÁRIA RESPONSABILIZAÇÃO POR ATOS CULPOSOS PRATICADOS NO EXERCÍCIO DA FUNÇÃO JURISDICIONAL}

Neste item, será analisada a incompatibilidade da imunidade dos magistrados -, na forma proposta pelo art. 143 do Código de Processo Civil -, com o ordenamento constitucional vigente.

\footnotetext{
${ }^{30}$ É o que ocorre, por exemplo, com os países que adotam o recall judiciário, onde o povo vai às urnas ratificar - ou censurar - os atos de natureza eminentemente política dos magistrados. Tendo em vista o estágio de evolução em que se encontra a frágil democracia brasileira (em que a opinião pública e as demais instâncias políticas ainda são facilmente manipuladas por interesses escusos), entende-se que, no caso dos membros do Poder Judiciário, deve restar prejudicada a responsabilidade política, que poderia configurar uma verdadeira ameaça à imparcialidade que deve nortear a função jurisdicional.
} 
Como é sabido, o Constituinte de 1988, com a finalidade de espancar as sombras do velho regime militar, consagrou, como primeira norma da Nova Constituição, o princípio republicano. Veja-se: "art. 1\%. A República Federativa do Brasil, formada pela união indissolúvel dos Estados e Municípios e do Distrito Federal, constitui-se em Estado democrático de direito (...)".

Nada poderia ser mais simbólico. Através deste expediente, o Constituinte de 1988 pretendeu demonstrar a inequívoca superação do regime anterior, demonstrando ao povo que a coisa pública lhe pertence.

De outro lado, a lei processual civil, originalmente editada em 1973, prevê:

"Art. 143. O juiz responderá, civil e regressivamente, por perdas e danos quando:

I - no exercício de suas funções, proceder com dolo ou fraude;

II - recusar, omitir ou retardar, sem justo motivo, providência que deva ordenar de ofício ou a requerimento da parte.

Parágrafo único. As hipóteses previstas no inciso II somente serão verificadas depois que a parte requerer ao juiz que determine a providência e o requerimento não for apreciado no prazo de 10 (dez) dias."

Uma interpretação mais apressada desta norma pode indicar que o intento do legislador foi limitar o caso de responsabilidade pessoal do magistrado aos casos de dolo ${ }^{31}$ ou fraude (ou, ainda, omissão injustificada, que, tendo em vista o objetivo do presente trabalho, deixará de ser considerada), excluindo o dever de reparar nos casos em que tenha agido com culpa, ainda que grave. ${ }^{32}$

Ocorre, todavia, que, como foi visto no item anterior, a responsabilização dos agentes públicos por atos danos provocados no exercício de sua função constitui a essência do princípio republicano. Assim, ao que parece, caso se pretenda consagra esta interpretação, há 2 (duas) normas no ordenamento jurídico pátrio que são incompatíveis entre si.

\section{Supremacia da Constituição}

Como bem anota Luis Roberto Barroso,

"toda interpretação constitucional se assenta no pressuposto da superioridade jurídica da Constituição sobre os demais atos normativos no âmbito do Estado. Por força da supremacia constitucional, nenhum ato jurídico, nenhuma manifestação de vontade pode subsistir validamente se for incompatível coma Lei Fundamental". ${ }^{33}$

Assim sendo, na hipótese de colisão entre 2 (duas) normas jurídicas, a primeira providência a ser tomada é verificar se alguma delas tem status constitucional. Em caso negativo, serão aplicados os postulados da

\footnotetext{
${ }^{31}$ Para os fins deste trabalho, pode-se definir o dolo como sendo a vontade conscientemente dirigida à produção de um resultado ilícito. Deste conceito, extrai-se que o dolo tem por elementos: i) a representação do resultado, que é a previsão, antevisão mental do resultado (antes de desencadear a conduta, o agente antevê, representa mentalmente, o resultado danoso e o elege como objeto de sua ação); e ii) a consciência da sua ilicitude, estando o agente consciente de que age de forma contrária ao dever jurídico, embora lhe seja possível agir de forma diferente.

32 Para os fins deste trabalho, pode-se conceituar a culpa como conduta voluntária contrária ao dever de cuidado imposto pelo direito, com a produção de um evento danoso involuntário, porém previsto ou previsível.

${ }^{33}$ In: Interpretação e Aplicação da Constituição, 6a ed., São Paulo: Saraiva, 2004, p. 158.
} 
especialidade (segundo o qual a lei especial suspende a eficácia da lei geral) e da revogação (pelo qual a lei posterior revoga a anterior no que for contrária).

Outrossim, em caso positivo, sendo uma das normas de hierarquia constitucional, afasta-se a incidência da outra norma. Na hipótese em tela, a norma constitucional (art. 1º, que prevê o regime republicano) deve prevalecer sobre a norma prevista na lei processual civil (art. 143, que prevê a imunidade dos magistrados). Neste passo, não resta dúvidas que, por ser ofensiva ao regime republicano, a irresponsabilidade civil dos magistrados, prevista em sede infra-constitucional, não encontra base no ordenamento pátrio

\section{A Falácia da Irresponsabilidade como uma Garantia à Autonomia da Função Jurisdicional}

Nem se fale que o art. 143 do Código de Processo Civil, ao limitar a responsabilidade dos magistrados às hipóteses de dolo ou fraude, teve por escopo alargar as garantias constitucionais para uma prestação jurisdicional independente, ${ }^{34}$ atendendo aos imperativos do art. $2^{\circ}$ da Constituição da República. ${ }^{35}$

Neste particular, importante foi a orientação firmada pelo Supremo Tribunal Federal ao declarar a constitucionalidade da Emenda Constitucional no 45/2004, que criou o Conselho Nacional de Justiça. Assentouse, ali, que as atribuições de controle ético-disciplinares deste novo órgão

"não acarreta imparcialidade jurisdicional, eis que representa expressiva conquista do Estado
Democrático de Direito a consciência de que os mecanismos de responsabilização dos
juízes, por inobservância das obrigações funcionais, são imprescindíveis à boa prestação
jurisdicional, sendo de reconhecer, como imperativo do regime republicano e da inteireza e
serventia da função, a necessidade de convívio permanente entre a independência
jurisdicional e instrumentos de responsabilização dos juízes que não sejam apenas formais,
mas que cumpram, com efetividade, o papel que se lhes predica". ${ }^{36}$

Deste modo - e diante da moldura republicana -, tal previsão legal: i) a uma, transborda as hipóteses de irresponsabilidade funcional previstas em numerus clausus pelo texto constitucional; ii) a duas, é totalmente desnecessária para a configuração de uma função jurisdicional autônoma; e iii) a três, é ofensiva ao princípio da igualdade entre as profissões. Vejamos cada item em tópicos distintos.

\section{$\underline{\text { O Sistema Constitucional de Garantias ao Exercício da Função Jurisdicional }}$}

Como é sabido, a Constituição de 1988 previu algumas garantias ao magistrado que, longe de terem sido previstas em razão da pessoa do agente público, funcionam como verdadeira proteção à independência do

\footnotetext{
${ }^{34}$ Segundo tal linha de pensamento, a norma infra-constitucional em análise apenas deu maior concre-tude à independência judiciária, através da previsão de mais uma garantia aos magistrados, não havendo qualquer inconstitucionalidade.

35 "Art. 2. São Poderes da União, independentes e harmônicos entre si, o Legislativo, o Executivo e o Judiciário."

${ }^{36}$ ADIn n 3.367/DF, rel. Min. Cezar Peluso, j. 13.04.2005.
} 
exercício da função jurisdicional. São elas a vitaliciedade, ${ }^{37}$ a inamovibilidade ${ }^{38}$ e a irredutibilidade de subsídio. ${ }^{39}$

Tais garantias não podem ser encaradas com privilégios, ${ }^{40}$ outorgadas em benefício dos próprios magistrados. Caso assim fossem entendidas, cairia por terra o princípio republicano, uma vez que sua luta sempre foi travada no sentido da extinção dos privilégios de determinadas classes sociais, próprios das monarquias absolutistas. Num regime autenticamente republicano, estas garantias devem ser entendidas como necessárias ao exercício da função pública exercida, sendo, portanto, garantia da própria instituição judiciária, não podendo funcionar, pois, como um verdadeiro "título de nobreza". ${ }^{41}$

Além destas garantias de independência dos órgãos judiciários, a Constituição da República prevê, como garantia da imparcialidade dos órgãos judiciários, determinadas vedações aos membros da magistratura. ${ }^{42}$ Assim é que o seu art. 95, parágrafo único, veda-lhes: i) exercer, ainda que em disponibilidade, outro cargo ou função, salvo uma de magistério; ii) receber, a qualquer título ou pretexto, custas ou participação em processo; e iii) dedicar-se à atividade político-partidária.

Em momento algum houve, por parte do Poder Constituinte Originário, previsão de um sistema de irresponsabilidade aos membros do Poder Judiciário. Em matéria de irresponsabilidade, houve apenas sua expressa previsão quanto alguns atos dos membros do Poder Legislativo (art. $53 \mathrm{CF})^{43}$ e ao Chefe do Poder Executivo (art. 86, $\left.\$ 4^{\circ} \mathrm{CF}\right) .^{44}$

Deste modo, esta irresponsabilidade civil, derivada da lei processual civil, não pode prosperar. Em sendo a República um princípio fundamental ${ }^{45}$ do Estado brasileiro - e sendo de sua essência a idéia de responsabilidade -, apenas podem ser admitidas como válidas as exceções previstas pela própria Constituição, ${ }^{46}$ o que, à toda

${ }^{37}$ Pela vitaliciedade, o juiz togado de $1^{\circ}$ grau, após 2 (dois) de efetivo exercício do cargo, não mais poderá perdê-lo senão por sentença transitado em julgado, pelo advento de aposentadoria compulsória ou disponibilidade.

${ }^{38}$ Pala inamovibilidade, o magistrado não pode ser removido do cargo para o qual foi nomeado, salvo se houver sua expressa manifestação de vontade ou na presença de interesse público, em decisão pelo voto de dois terços do Tribunal a que estiver vinculado.

${ }^{39}$ Pela irredutibilidade de subsídios, tem-se que os subsídios dos magistrados não podem ser diminuídos nem mesmo em virtude de medida geral.

${ }^{40}$ Enquanto a garantia tem natureza objetiva, por visar proteger o desempenho regular de uma função, o privilégio é puramente subjetivo, outorgado em razão da pessoa. A saga republicana tem por finalidade, justamente, extinguir todos os privilégios aristocráticos, inserindo, quando for o caso, certas garantias para o desempenho das funções públicas.

${ }^{41}$ Devo esta feliz alusão ao colega de mestrado e Procurador da República, José Gomes Ribeiro Schettino.

${ }^{42}$ SILVA, José Afonso da. Curso de Direito Constitucional Positivo, 19a ed., São Paulo: Malheiros, 2001, p. 580.

43 "Art. 53. Os Deputados e Senadores são invioláveis, civil e penalmente, por quaisquer de suas opiniōes, palavras e votos."

44 "Art. 86 (...) $₫ 4^{\circ}$. O Presidente da República, na vigência de seu mandato, não pode ser responsabilizado por atos estranhos ao exercício de suas funções."

${ }^{45}$ Segundo Luis Roberto Barroso, são fundamentais os princípios que contenham decisões políticas estruturais do Estado, constituindo, pois, a síntese de todas as demais normas constitucionais, vez que estas podem ser direta ou indiretamente reconduzidas àquelas. In: Interpretação e Aplicação da Constituição, 6a ed., São Paulo: Saraiva, 2004, p. 155.

${ }^{46}$ In casu, não se pode sequer falar que as hipóteses de irresponsabilidade consagradas pela Constituição de 1988 aos membros do Poder Legislativo e para o Chefe do Executivo são exceções ao princípio republicano. A primeira, por abranger os crimes de palavra, tem por finalidade, justamente, consagrar a independência política dos membros do Congresso Nacional. A segunda, por 
evidência, não é o caso.

\section{Irrazoabilidade da Imunidade Civil dos Magistrados}

Ainda que a irresponsabilidade por culpa pudesse ser inserida em sede infra-constitucional - o que se admite, aqui, por exclusivo amor ao debate -, verifica-se que a mesma não é apta a atingir a finalidade que se propõe, padecendo de evidente irrazoabilidade.

Para quem não sabe, o postulado da razoabilidade permite um eficaz controle da discricionariedade legislativa e administrativa. Através dele, é possível invalidar atos legislativos ou administrativos quando: i) não haja adequação entre o fim perseguido e o meio empregado pelo mesmo (razoabilidade-adequação); ii) a medida não seja exigível ou necessária, havendo um caminho alternativo para chegar ao mesmo resultado com menor ônus a um direito individual (razoabilidade-necessidade); iii) não haja proporcionalidade em sentido estrito, ou seja, o que se perde com a medida tem maior relevo do que aquilo que se ganha (razoabilidadeproporcionalidade). ${ }^{47}$

Com apoio na idéia de que a irresponsabilidade civil seria um pressuposto necessário à sua independência funcional, é que Mário Guimarães sustenta que se os magistrados fossem "obrigados a ressarcir, de seu bolso, os danos causados, ficariam tolhidos, pelo receio do prejuízo próprio, na sua liberdade de apreciação dos fatos e de aplicação do direito". ${ }^{48}$ Trata-se de posição que, além de exacerbar, de forma caricata, o corporativismo, ínsito a todas as instituições, ${ }^{49}$ não passa num simples teste de razoabilidade.

Ocorre que a irresponsabilidade civil dos magistrados, além de não ser uma "garantia" prevista na Constituição da República, não pode constituir o preço que a coletividade é chamada a pagar em troca da sua independência funcional. ${ }^{50}$ Pode-se, deste modo, afirmar que a irresponsabilidade judiciária é um preço muito alto a ser pago para a configuração de um Poder Judiciário independente, pelo menos num Estado republicano. Logo, restaria vulnerada a segunda dimensão do postulado da razoabilidade (necessidade), uma vez que o direito difuso a um regime de direito republicano não pode ser privado em nome da independência da função jurisdicional: outras formas para o atingimento desta finalidade devem ser encontradas pelo legislador.

configurar uma suspensão temporária de responsabilidade, justifica-se tendo em vista a necessidade de dedicação integral do Chefe do Executivo à coisa pública, durante a vigência de seu mandato.

47 BARROSO, Luis Roberto. Temas de Direito Constitucional. Vol. I, Rio de Janeiro: Renovar, 2001, p. 163.

${ }^{48}$ Apud CAVALIERI, Sérgio. op. cit., p. 267.

${ }^{49}$ OLSON, Mancur. A Lógica da Ação Coletiva. São Paulo: Edusp, 1999, p. 18.

${ }^{50}$ CAPELETTI, Mauro. op. cit., p. 33. 


\section{Da Ofensa ao Princípio da Igualdade entre as Profissões}

Outrossim, tal previsão em sede infra-constitucional ofende o princípio da igualdade entre as profissões, previsto, de forma genérica, no art. $5^{\circ}$, caput da Constituição da República ${ }^{51}$, e, de forma específica, embora dirigida imediatamente às relações jurídicas tributárias, pelo art. 150, II do mesmo Documento. ${ }^{52}$

Ao se consagrar tal posição - de irresponsabilidade judicial -, também deveria ser suprimida, por exemplo, a responsabilidade do médico por danos advindos de atos culposos que, no exercício de sua profissão, viesse a causar a terceiros. Em se admitindo esta responsabilização - segundo esta lógica -, restaria tolhida a sua liberdade de apreciação dos fatos e escolha da melhor intervenção clínica ao paciente. Nada mais absurdo.

E nem se fale que o grande número de processos sob a guarda de cada magistrado seria justificativa para tal irresponsabilidade. Se assim fosse, a grande maioria dos brasileiros (sejam médicos, engenheiros, professores ou advogados, por exemplo) também deveria ser beneficiada pela garantia da irresponsabilidade civil, uma vez que o excesso de trabalho não é um "privilégio" outorgado pelo mercado de trabalho apenas aos magistrados.

Talvez, apenas uma visão corporativista ${ }^{53}$ - extremamente nociva aos verdadeiros ideais republicanos seja capaz de afirmar tamanha atrocidade, capaz de jogar por terra o valor da igualdade, cuja lenta construção e consolidação já consome alguns séculos de nossa história. ${ }^{54}$

E mais. Quando, para esquivar-se de eventual obrigação reparatória, o Estado ou o particular invocam o excesso de trabalho, o Poder Judiciário geralmente reconhece que a parte que sofreu o dano não pode ser prejudicada por fato de terceiro e que o mesmo não pode ser invocado como razão suficiente para impedir a responsabilização civil. Será razoável que, em causa própria, admita esta excludente de responsabilidade? Dois pesos, duas medidas: nada mais temerário às instituições republicanas.

De fato, há bons e maus profissionais em todos os ramos da atividade humana. Por acaso seria diferente

\footnotetext{
51 "Art. $5^{\circ}$ Todos são iguais perante a lei, sem distinção de qualquer natureza, garantindo-se aos brasileiros e aos estrangeiros residentes no País a inviolabilidade do direito à vida, à liberdade, à igualdade, à segurança e à propriedade (...)”.

52 "Art. 150. Sem prejuízo de outras garantias asseguradas ao contribuinte, é vedado à União, aos Estados, ao Distrito Federal e aos Municípios: (...) II - instituir tratamento desigual entre contribuintes que se encontrem em situação equivalente, proibida qualquer distinção em razão de ocupação profissional ou função por eles exercida, independentemente da denominação jurídica dos rendimentos, títulos ou direitos."

53 Novamente faz-se necessária a menção ao acórdão proferido pelo Supremo Tribunal Federal na Ação Direta de Inconstitucionalidade no 3.367/DF, que declarou a constitucionalidade do Conselho Nacional de Justiça. Segundo a Corte, "a existência, no Conselho, de membros alheios ao corpo da magistratura, além de viabilizar a erradicação do corporativismo, estende uma ponte entre o Judiciário e a sociedade, permitindo a oxigenação da estrutura burocrática do Poder e a resposta a críticas severas".

${ }^{54}$ Neste particular, apresenta-se emblemático um caso ocorrido no Estado do Rio de Janeiro, que bem demonstra este sentimento de pseudo-superioridade que acomete alguns magistrados. Conforme amplamente divulgado pelos meios de comunicação, já houve um caso em que determinado juiz estadual buscou, em sede de ação cominatória, o "direito" de ser chamado de Doutor ou de Excelência pelos funcionários e vizinhos do prédio onde morava. Se mesmo no exercício de suas funções judicantes a existência de tal obrigação jurídica já é questionável (é lógico, contudo, que a prática forense recomenda tal tratamento), querer estender tal
} 
com o Poder Judiciário? Serão citados, aqui, 2 (dois) exemplos de atuação jurisdicional, colhidos no dia-a-dia do foro brasileiro, cada um demonstrando um dos lados da atividade jurisdicional.

O primeiro é merecedor de profundas críticas. Há alguns anos atrás, determinado magistrado, titular de uma das comarcas litorâneas do Estado Brasileiro, ${ }^{55}$ determinou a prisão civil de certo "devedor" de alimentos. A ordem de prisão foi cumprida, em horário de expediente, tendo o "devedor" sido algemado e preso na frente de todos os seus colegas de trabalho. Ocorre, contudo, que o "devedor", antes mesmo da decretação de sua prisão, já havia cumprido sua obrigação e pago os referidos alimentos, sendo que o respectivo comprovante estava anexado aos autos judiciais no momento daquela decisão (!). Trata-se, no mínimo, de hipótese de culpa grave do magistrado, que expediu o decreto de prisão sem a análise cuidadosa dos autos.

Outro exemplo, merecedor de profundos elogios, ocorreu no Amapá, e demonstra o verdadeiro espírito cívico que deveria informar a atuação de todos os membros da magistratura nacional. Segundo consta, ${ }^{56}$ o juiz eleitoral Romeu Araújo, às vésperas da eleição municipal do ano de 2004, recebeu uma denúncia de que determinada candidata à vereança estaria comprando votos de eleitores humildes. No dia da eleição, o juiz, disfarçado de mendigo, compareceu ao seu Comitê Eleitoral e constatou a prática do crime, dando voz de prisão ao sobrinho da candidata, que agenciava a compra de votos. O processo contra a candidata, até onde se sabe, corre na Justiça Eleitoral daquele Estado e tem o referido juiz como principal testemunha.

Agora, a pergunta: se forem indagados ambos os magistrados, qual deles teria oposições à consagração de responsabilização civil por dano oriundo de ato jurisdicional culposo? A resposta parece óbvia.

Neste passo (e em complementação ao subitem anterior), parece forçoso reconhecer que a irresponsabilidade não configura garantia alguma à autonomia da função judicante. Ao revés, configura, tãosomente, uma garantia ao mal profissional da justiça, que pretende usar esta "garantia" como verdadeiro manto para seus desmandos e eventuais propósitos de duvidosa licitude.

Não é possível ver a irresponsabilidade civil como uma tentativa de se consagrar a autonomia da função jurisdicional, pois esta não é um instrumento efetivo para o atingimento de tal desiderato. ${ }^{57}$ Em não sendo um instrumento efetivo, verifica-se que tal garantia passa a conferir verdadeiro privilégio, insustentável num regime republicano.

\footnotetext{
"obrigação" às relações privadas do magistrado parece uma piada de mau gosto, uma falta de senso crítico ou, no mínimo, uma incapacidade de se situar social ou historicamente..

${ }^{55}$ Este foi um caso que coletei na minha experiência como advogado. Não será feita, aqui, referência ao número do processo nem a maiores especificações sobre o caso, em respeito ao segredo de justiça em que o mesmo tramitava, tendo em vista que a questão versada era atinente a direito de família.

${ }^{56}$ Este fato foi noticiado na página 12 do Jornal "O Globo" do dia 19 de novembro de 2004.

${ }^{57}$ Ainda que fosse, a perda marginal na adoção da irresponsabilidade judicial não justifica sua previsão em nosso sistema republicano. Esta idéia foi desenvolvida no subitem 2.2.2.
} 


\section{CONSIDERAÇÕES FINAIS}

Por necessidade de síntese didática, verifica-se que as idéias desenvolvidas no presente texto podem ser condensadas em proposições objetivas, a saber:

1. A República é o regime político em que os exercentes de funções políticas (executivas e legislativas) representam o povo e decidem em seu nome, fazendo-o com responsabilidade. A simples menção ao termo já evoca um universo de conceitos intimamente relacionados entre si. Dentre tais conceitos, o de responsabilidadeé essencial.

2. Quer se considere a função jurisdicional como uma função técnica ou como uma função política, o princípio republicano deve informar seu exercício, através da implementação de responsabilidade ao agente que venha a provocar danos a terceiros.

3. Longe de se exaurir na esfera política, a responsabilização do agente público pode ter consequiências jurídicas, configurando-se como crime, como ato desabonador da honra objetiva das instituições juspolíticas ou como ilícito civil.

4. Os excessos e os desvios de poder, ao lado de decisões manifestamente imprudentes, devem dar ensejo à responsabilização civil, seja regressiva, seja ordinária, quando o lesado é o patrimônio público ou privado.

5. Uma interpretação superficial do art. 143 do Código de Processo Civil pode indicar que o intento do legislador foi limitar o caso de responsabilidade pessoal do magistrado aos casos de dolo, fraude ou omissão injustificada, excluindo o dever de reparar nos casos em que tenha agido com culpa, ainda que grave.

6. Não obstante, tal interpretação é contrária ao princípio republicano, uma vez que a responsabilização dos agentes públicos por atos danos provocados no exercício de sua função constitui a sua essência.

7. A previsão de imunidade judicial, a um só tempo: i) transborda as hipóteses de irresponsabilidade funcional previstas em numerus clausus pelo texto constitucional; ii) é totalmente desnecessária para a configuração de uma função jurisdicional autônoma; e iii) é ofensiva ao princípio da igualdade entre as profissões.

8. O artigo 143 do Código de Processo Civil, bem quaisquer outras normas similares que tentem limitar a responsabilidade civil de agentes públicos por danos praticados através de conduta culposa, são inconstitucionais, por ofensa ao princípio republicano (art. $1^{\circ}$ ), por ofensa ao sistema de imunidades materiais esboçado pelo Constituinte Originário e por ofensa ao princípio da igualdade entre as profissões (art. 5o, II). 


\section{REPUBLIC AND CIVIL LIABILITY OF JUDGES}

\section{Abstract}

Article 143 of the Brazilian Code of Civil Procedure limits the civil liability of magistrates for damages caused to the cases of fraud or intentional misconduct. Such a limitation, in addition to offending the republican principle, does not find grounds in the system of material immunities provided by the Brazilian Constitution.

Keywords: Article 143. Brazilian Code of Civil Procedure. Unconstitutionality. Republican clause.

\section{BIBLIOGRAFIA}

ATALIBA, Geraldo. Constituição e República, 2ª ed., São Paulo: Malheiros, 1998.

ÁVILA, Humberto. Teoria dos Princípios. 4a ed., São Paulo: Malheiros, 2005.

BARROSO, Luis Roberto. Interpretação e Aplicação da Constituição, 6a ed., São Paulo: Saraiva, 2004.

Temas de Direito Constitucional. Vol. I, Rio de Janeiro: Renovar, 2001.

BARROSO, Luis Roberto et BARCELlOS, Ana Paula de. "O Começo da História: a Nova Interpretação Constitucional e o Papel dos Princípios no Direito Brasileiro”. In: A Nova Interpretação Constitucional, Rio de Janeiro: Renovar, 2003.

BERTEN, André. Republicanismo e Motivação Política. In: Direito e Legitimidade, São Paulo: Landy Editora, 2003.

BONAVIDES, Paulo. Teoria do Estado. 6a ed., São Paulo: Malheiros, 1996.

CALAMANDREI, Piero. Eles, os Juízes, Vistos por um Advogado. São Paulo: Martins Fontes, 1995.

CAPELETTI, Mauro. Juízes Irresponsáveis?, Porto Alegre: Sérgio Antônio Fabris Editor, 1989.

CAVALIERI, Sérgio. Programa de Responsabilidade Civil, $5^{a}$ ed., São Paulo: Malheiros, 2003.

DALLARI, Dalmo de Abreu. Elementos de Teoria Geral do Estado, 20a ed., São Paulo: Saraiva, 1998.

HART, Hebert. O Conceito de Direito. 2a ed., Lisboa: Calouste Gulbenkian, 1994.

KELSEN, Hans. Teoria Pura do Direito, 2a ed., São Paulo: Martins Fontes, 2001.

MEDAUAR, Odete. Direito Administrativo Moderno. 5a ed., São Paulo: Revista dos Tribunais, 2001.

OLSON, Mancur. ALógica da Ação Coletiva. São Paulo: Edusp, 1999.

PENNA, Lincoln de Abreu. República Brasileira. Rio de Janeiro: Nova Fronteira, 1999.

PETTIT, Philip. Republicanismo (Uma Teoria sobre la Liberdad y el Gobierno). Barcelona: Paidós, 2000. 
SILVA, José Afonso da. Curso de Direito Constitucional Positivo, 19a ed., São Paulo: Malheiros, 2001.

TEPEDINO, Gustavo. Temas de Direito Civil. Rio de Janeiro: Renovar, 2001.

Trabalho enviado em 16 de julho de 2017.

Aceito em 17 de julho de 2017. 